\title{
ANALISIS PEMBERIAN DANA DESA DALAM PENURUNAN ANGKA KEMISKINAN DI PROVINSI BENGKULU
}

\author{
Oleh: \\ Harmiati*, Mulyadi, Evsa Wulan Suri, Deni Triyanto \\ Email : harmiati.m.si1961@gmail.com

\section{Program Studi Administrasi Publik Fakultas Ilmu Sosial dan Ilmu Politik Universitas Prof. Dr. Hazairin, SH Bengkulu}

\begin{abstract}
ABSTRAK
Tujuan penelitian ini adalah untuk meneliti pengaruh pemberian dana desa terhadap penurunan angka kemiskinan di Provinsi Bengkulu. Data yang digunakan adalah data kemiskinan pada sembilan Kabupaten di Provinsi Bengkulu dari tahun 2015 -2018. Alat analisis yang digunakan adalah Scatter Plot Korelasi dengan data panel untuk melihat korelasi antara tingkat kemiskinan dengan besarnya dana desa yang diterima masing-masing Kabupaten di Provinsi Bengkulu tahun 2015-2018. Hasil analisis dapat disimpulkan bahwa penurunan kemiskinan tidak berkorelasi dengan pemberian dana desa pada Kabupaten di Provinsi Bengkulu. Sehingga tujuan pemberian dana desa untuk peningkatan perekonomian dan kesejahteraan masyarakat belum tercapai.
\end{abstract}

Kata kunci: Dana Desa, Kemiskinan, Peningkatan Ekonomi, Kesejahteraan 
MIMBAR

JURNAL PENELITIAN SOSIAL DAN POLITIK

\section{A. Pendahuluan}

Kemiskinan masih menjadi topik penting yang diperhatikan dari berbagai kalangan karena melibatkan banyak aspek dan bersifat multidimensional. Dalam dimensi ekonomi, konsep yang sering digunakan dalam mengidentifikasi kemiskinan adalah banyaknya kelompok masyarakat yang hidup di bawah garis kemiskinan (below poverty line). Dalam ukuran lainnya, UNDP mengidentifikasikan kemiskinan sebagai kelompok masyarakat dengan pendapatan kurang dari 1,25 dollar perhari sesuai kemampuan daya beli atau purchasing power parity.

Sejak tahun 1997-1999 Indonesia menjadi porak poranda dilanda krisis moneter berkepanjangan meluas menjadi krisis ekonomi menyebabkan kemunduran berbagai kegiatan ekonomi, terganggunya kegiatan produksi, dan distribusi, sehingga penduduk miskin di Indonesia meningkat. Jumlah penduduk miskin pada periode 19961998 meningkat dengan tajam dari 22,5 juta jiwa $(11,3 \%)$ menjadi 49,5 juta jiwa $(24,2 \%)$ atau bertambah sebanyak 27,0 juta jiwa (BPS, 1999). Jumlah penduduk miskin pasca krisis ekonomi telah berangsur membaik, angka kemiskinan perlahan-lahan menurun. Hal ini menandakan perekonomian Indonesia telah semakin membaik. Namun timbul suatu pertanyaan apakah penurunan jumlah angka kemiskinan ini sebagai dampak keberhasilan program pemberian bantuan untuk pengentasan kemiskinan ataukah karena penyebab lainnya.

Pada tahun 2000-2018 jumlah penduduk miskin secara perlahan-lahan mengalami penurunan dari 19,14 persen atau 38,74 jiwa tahun 2000 menjadi 9,82 persen atau 25,95 juta jiwa pada tahun 2018. Penurunan penduduk miskin selama tahun 2000 - 2018 sebesar 9,32 persen atau 8,79 juta jiwa. Kondisi ini menandakan perekonomian Indonesia secara bertahap meningkat (Arif, 2010). Namun 40,00 persen kelompok termiskin penduduk Indonesia hanya bisa menikamati share 19,2 persen, sementara 20 persen kelompok terkaya menikmati 45,72 persen pertumbuhan ekonomi (BPS, 2015).

Penduduk miskin di wilayah pedesaan jauh lebih besar dibandingkan dengan penduduk miskin diwilayah perkotaan. Data BPS 2017, mencatat penduduk miskin di perkotaan turun sebanyak 128,2 ribu jiwa dari 10,27 juta jiwa menjadi 10,14 juta jiwa pada tahun 2018. Sementara di pedesaan penduduk miskin turun 505 ribu jiwa dari 16,31 juta jiwa menjadi 15,81 juta jiwa pada taun 2018. Secara agregat, persentase penduduk miskin terhadap total populasi memang lebih besar di wilayah perkotaan dibandingkan dengan pedesaan.

Kemiskinan menjadi perhatian penting dalam pembangunan sesuai dengan Undang Undang No.17 Tahun 2007 tentang Rencana Pembangunan Jangka Panjang Nasional Tahun 2005-2025, bahwa jumlah penduduk miskin masih cukup tinggi, baik di pedesaan maupun perkotaan terutama pada sektor pertanian dan kelautan, sehingga penanggulangan kemiskinan menjadi prioritas utama. Hal ini sesuai dengan tujuan utama Sustainable Development Goals (SDGs) adalah menghilangkan kemiskinan. Bengkulu merupakan provinsi yang belum siap untuk mencapai target utama 16 SDGs pada tahun 2030 (Alisjahbana dkk. 2018).

Provinsi Bengkulu merupakan provinsi termiskin kedua di pulau Sumatera setelah Aceh. Data BPS tahun 2018 memperlihatkan penduduk miskin di Provinsi Bengkulu sebesar 15,43 persen (301.814) jiwa, jumlah penduduk miskin menurun 0,16 persen dibandingkan dengan tahun 2017 sebesar 15,59 persen (302.622) jiwa. Tingginya angka kemiskinan di Bengkulu disebabkan penduduk yang bekerja sebagian besar hanya Tamatan SD, disamping itu tingginya jumlah pengangguran menyebabkan pertumbuhan ekonomi yang rendah (Afriyanti, 2016).

Program pengentasan kemiskinan telah banyak dilakukan oleh pemerintah seperti; Inpres Desa Tertinggal (IDT), Program Keluarga Harapan (PKH), Program Beras Sejahtera (Rastra), Program Bantuan Langsung Tunai (BLT), Kredit Usaha Rakyat (KUR), dan Keridit Usaha Bersama (KUBE), Raskin, Kartu Indonesia Pintar (KIP) dll. Namun program pengentasan kemiskinan yang dilaksanakan oleh pemerintah pusat dan daerah belum memberikan implikasi yang cukup signifikan (Arif, 2010). Masih terjadi ketimpangan pembangunan dan kesejahteraan masyarakat dipedesaan. Lahirnya Undang-Undang No 6 tahun 2014 tentang Desa merupakan landasan yang kuat dalam pelaksanaan pembangunan desa 
MIMBAR

JURNAL PENELITIAN SOSIAL DAN POLITIK

Juni 2019

dalam rangka peningkatan perekonomian dan penurunan angka kemiskinan. Peraturan Pemerintah Nomor 60 Tahun 2014 tentang Dana Desa, pada Pasal 19 berbunyi Dana Desa digunakan untuk membiayai penyelenggaraan pemerintahan, pembangunan, dan pemberdayaan serta kemasyarakatan.

Pengelolaan dana desa untuk pembangunan dan pemberdayaan masyarakat belum optimal, terutama bidang perencanaan, pencapaian sasaran dan pemanfaatan tenaga kerja lokal. Hasil penelitian Lalira dkk. (2018), menemukan bahwa dana desa tidak berpengaruh secara signifikan terhadap penurunan angka kemiskinan di Kecamatan Gemeh Kabupaten Talaud, pengalokasian dana desa untuk pemberdayaan masyarakat dan penurunan angka kemiskinan belum jelas, dalam pembangunan infrastruktur tidak memprioritaskan tenaga kerja dari masyarakat desa, sehingga pemberdayaan masyarakat belum terwujud dan angka kemiskin tidak menurun. Penelitian Sari dan Abdullah (2017), di Kabupaten Tulung Agung tentang Analisis Ekonomi Kebijakan Dana Desa terhadap Kemiskinan juga menemukan bahwa dana desa tidak efektif mengurangi kemiskinan. Menurut Sari sebanyak 114 Desa (84 persen) penggunaan dana desa untuk pembangunan sarana dan prasarana perdesaan dengan perencanaan yang kurang baik dan kualitas bangunan yang buruk, sedangkan dana desa untuk pemberdayaan ekonomi masyarakat hanya 6,5 persen. Demikan juga penelitian Hendra dkk. (2017), menemukan bahwa dana desa belum dapat berkontribusi dalam penurunan angka kemiskinan, karena pemerintah desa belum dapat memilih pembangunan infrastruktur yang berdampak ekonomi.

Berbagai hasil penelitian tersebut dapat disimpulkan bahwa perencanaan, pelaksanaan pembangunan desa yang belum optimal dalam penurunan angka kemiskinan karena rendahnya keberfungsian sosial secara individu dan masyarakat. Menurut Edi Suharto (2009), pendekatan ini mengarah pada pendekatan demokrasi sosial. Pendekatan ini menekankan pada cara yang dilakukan individu-individu dan kelompok dalam melaksanakan tugas untuk memenuhi kebutuhan hidup masyarakatnya. Fokus utama dari pendekatan ini adalah pada kapabilitas individu, keluarga atau masyarakat. Dalam menjalankan peranperan sosial dilingkungan masyarakat. Salah satu teori yang mendukung paradigma keberfungsian sosial adalah teori yang dikemukakan oleh Baker, Dubois dan Miley (1992). Teori tersebut menyatakan bahwa keberfungsian sosial berkaitan dengan kemampuan seseorang dalam memenuhi kebutuhan dasar diri dan keluarganya serta dalam memberikan kontribusi positif dalam masyarakat. Teori tersebut dapat diaplikasikan dalam pemanfaatan dana desa untuk menurunkan angka kemiskinan.

Dalam pemanfaatan dana desa banyak kendala yang dihadapi seperti; perencanaan program pemanfaatan dana desa kurang tepat, pengawasan dan evalusi penggunaan dana desa juga belum melibatkan masyarakat secara optimal. Hal ini menunjukkan bahwa keberfungsian sosial pada masyarakat desa belum berjalan dalam memenuhi kebutuhan individu, keluarga dan memberikan kontribusi yang positif dalam masyarakat desa. Pemanfaatan dana desa yang tepat dan bernilai ekonomi bagi masyarakat desa dapat berimplikasi terhadap pengurangan angka kemiskinan. Tulisan ini mencoba mengkaji hubungan antara pemanfaatan dana desa terhadap penurunan angka kemiskinan pada tiap-tiap kabupaten di Provinsi Bengkulu dari tahun 2015 sampai dengan tahun 2018.

\section{B. Metode Penelitian}

Data yang digunakan adalah data kemiskinan dan jumlah Dana Desa yang diterima oleh sembilan Kabupaten di Provinsi Bengkulu yaitu; Kabupaten Kaur, Kabupaen Bengkulu Selatan, Kabupaten Seluma, Kabupaten Bengkulu Utara, Kabupatan Muko-Muko, Kabupaten Bengkulu Tengah, Kabupaten Rejang Lebong dan Kabupaten Lebong. Data diambil dalam kurun waktu 4 tahun dari tahun 2015 sampai tahun 2018. Data yang digunakan adalah data sekunder dari tahun 2015 - 2018 yang merupakan data Panel. Data panel merupakan kombinasi antara data silang tempat cross-section dengan data runtun waktu time series (Kunchoro 2011). Alat analisis yang digunakan adalah Scatter Plot Korelasi.

Analisis ini bertujuan untuk melakukan pengujian seberapa kuatnya hubungan antara 
MIMBAR

JURNAL PENELITIAN SOSIAL DAN POLITIK

Juni 2019

pemanfaatan dana desa terhadap penurunan angka kemiskinan pada sembilan Kabupaten di Provinsi Bengkulu, disamping itu untuk menentukan jenis hubungan apakah positif atau negatif atau tidak adanya hubungan sama sekali antara variabel $\mathrm{X}$ (kemiskinan) dan Variabel Y (dana desa)

\section{Hasil Penelitin dan Pembahasan}

Sasaran pemberian dana desa adalah pemerintah desa dan masyarakat dalam rangka menunjang pelaksanaan pemerintahan desa, pembangunan dan pemberdayaan masyarakat dengan tujuan meningkatkan perekonomian dan kesejahteraan masyarakat pedesaan (Buku Saku Dana Desa 2017). Dari hasil penelitian dapat dilihat bahwa pemberian dana desa di Indonesia selama kurun waktu empat tahun sejak tahun 2015-2018 sebagaimana Tebal 1 berikut :

Tabel.1. Pemberian Dana Desa di Indonesia Tahun 2015 -2018

\begin{tabular}{|l|c|c|l|}
\hline No & Tahun & $\begin{array}{c}\text { Dana Desa } \\
\text { (dalam ribuan) }\end{array}$ & Persentase \\
\hline 1 & 2015 & 20.766 .200 .000 & 11,00 \\
\hline 2 & 2016 & 46.982 .080 .000 & 24,25 \\
\hline 3 & 2017 & 60.000 .000 .000 & 30,97 \\
\hline 4 & 2018 & $60.000 .000 .000 *$ & 30,97 \\
\hline & & & 100.00 \\
\hline
\end{tabular}

Sumber Data: Buku Saku Dana Desa tahun 2017 dan * http://www.djpk.depkeu.go.id

Pada Tabel 1. dapat dilihat bahwa jumlah dana desa yang diberikan diseluruh Indonesia sajak tahun 2015 sampai dengan tahun 2018 sebesar Rp. 193.748.280.000,pada tahun 2015 sampai dengan 2017 terjadi peningkatan pemberian dana desa, akan tetapi untuk tahun 2017 dan tahun 2018 jumlah dana desa yang diberikan tidak mengalami kanaikan, pada dua tahun tersebut dana desa yang diberikan berjumlah Rp. 60.000.000.000,- per tahun. Provinsi Bengkulu memiliki sembilan kabupaten yaitu; Kabupaten Bengkulu Selatan, Kabupaten Rejang Lebong, Kabupaten Bengkulu Utara, Kabupaten Kaur, Kabupaten Seluma, Kabupaten Muko-Muko, Kabupaten Lebong, Kabupaten Kepahiang, Kabupaten Bengkulu Tengah mendapat dana desa sebagaimana tabel 2 berikut :

\begin{tabular}{|c|c|c|c|c|c|c|}
\hline \multirow[b]{2}{*}{ No } & \multirow[b]{2}{*}{ Kabupaten } & \multicolumn{4}{|c|}{ Dana Desa (dalam Ribuan) } & \multirow{2}{*}{$\begin{array}{c}\text { Jumlah } \\
\text { (dalam ribuan Rp) }\end{array}$} \\
\hline & & 2015 & 2016 & 2017 & 2018 & \\
\hline 1 & Bengkulu Selatan & 38.790 .715 & 87.029 .059 & 110.746 .649 & 97.393 .929 & 333.960 .352 \\
\hline 2 & Rejang Lebong & 33.338 .960 & 74.796 .332 & 166.310 .259 & 97.025 .890 & 371.471 .441 \\
\hline 3 & Bengkulu Utara & 58.318 .640 & 130.594 .550 & 95.495 .934 & 146.743 .965 & 431.153 .089 \\
\hline 4 & Kaur & 51.138 .239 & 114.705 .102 & 145.777 .851 & 29.967 .425 & 341.588 .617 \\
\hline 5 & Seluma & 48.899 .525 & 109.690 .905 & 139.486 .234 & 126.493 .638 & 424.570 .302 \\
\hline 6 & Mukomuko & 40.360 .009 & 90.529 .932 & 115.058 .353 & 106.523 .093 & 352.471 .387 \\
\hline 7 & Lebong & 25.447 .255 & 56.982 .592 & 72.563 .476 & 68.334 .766 & 223.328 .089 \\
\hline 8 & Kepahiang & 28.660 .854 & 64.305 .935 & 81.496 .596 & 74.958 .035 & 249.421 .420 \\
\hline 9 & Bengkulu Tengah & 38.008 .042 & 85.262 .139 & 108.405 .061 & 98.197 .538 & 329.872 .780 \\
\hline & Jumlah & 362.962 .239 & 813.896 .546 & 1.035 .340 .413 & 845.638 .279 & 3.057 .837 .477 \\
\hline
\end{tabular}

Pada Tabel 2. dapat dilihat bahwa Kabupaten Bengkulu Utara merupakan penerima dana desa terbesar berjumlah $\mathrm{Rp}$ 431.153.089.000,- selama empat tahun dari tahun 2015 sampai dengan tahun 2018. Kabupaten Seluma penerima dana desa terbesar kedua berjumlah Rp. 424.570.302.000,-. Kabupaten Rejang Lebong merupakan penerima dana desa terbesar ketiga berjumlah Rp.371.471.441.000,-. Sedangkan Kabupaten Lebong menerima dana desa terkecil dengan jumlah Rp.223.328.420.000,-. $\quad$ Kabupaten Kepahiang penerima dana desa terkecil kedua berjumlah Rp 249.421.420.000,-.

Dari data tersebut dapat dilihat apakah Kabupaten penerina dana desa tertinggi dapat menurunkan angka kemiskinan atau Kabupaten yang terendah menerima dana desa dapat menurunkan angka kemiskinan. Provinsi Bengkulu merupakan provisni termiskin nomor 2 di wilayah bagian Barat dengan angka kemiskinan tiap-tiap kabupaten sebagaimana tabel. 3 berikut ; 
MIMBAR

JURNAL PENELITIAN SOSIAL DAN POLITIK

Tabel.3. Penduduk Miskin berdasarkan Kabupaten di Provinsi Bengkulu tahun 2015-2018
\begin{tabular}{|l|c|c|r|r|}
\hline \multirow{2}{*}{ Kabupaten } & \multicolumn{5}{|c|}{ Jumlah Penduduk Miskin (dalam persen) } \\
\cline { 2 - 5 } & 2015 & 2016 & 2017 & 2018 \\
\hline Bengkulu Selatan & 22,76 & 22,1 & 21,06 & 18,65 \\
\hline Rejang Lebong & 18,03 & 17,81 & 16,97 & 16,23 \\
\hline Bengkulu Utara & 14,78 & 13,67 & 13,11 & 11,81 \\
\hline Kaur & 22,87 & 22,36 & 21,54 & 19,4 \\
\hline Seluma & 22,98 & 21,68 & 20,73 & 19,6 \\
\hline Mukomuko & 13,45 & 13,01 & 12,20 & 11,4 \\
\hline Lebong & 12,32 & 12,26 & 11,83 & 11,59 \\
\hline Kepahiang & 16,83 & 16,31 & 15,95 & 14,42 \\
\hline Bengkulu Tengah & 8,93 & 8,71 & 8,41 & 8,2 \\
\hline
\end{tabular}

Sumber Data: BPS Provinsi Bengkulu tahun 2018,

Dari tabel 3 dapat dilihat bahwa Kabupatan Seluma memiliki penduduk miskin tertinggi mencapai 22,98 persen, Kabupaten Kaur menduduki urutan kedua penduduk miskin dengan angka mencapai 22,87 persen, Kabupaten Bengkulu Selatan menempati urutan ketiga penduduk miskin tertinggi berjumlah 22,76 persen. Sedangkan persentase penduduk miskin yang terendah Kabupaten Bengkulu Tengah, pada tahun 2015 persentase penduduk miskin hanya 8,93 persen, Kabupaten Muko-Muko merupakan urutan kedua penduduk miskin terendah tahun 2015 hanya 13,35 persen. Akan tetapi secara umum persentase penduduk miskin diseluruh kabupaten wilayah Provinsi Bengkulu secara perlahanlahan semakin menurun sejak tahun 2015 sampai 2018. Dari data tersebut dapat dilihat bahwa besarnya dana desa yang diterima tidak berpengaruh terhadap persentase penurunan angka kemiskinan pada tiap-tiap Kabupaten di Provinsi Bengkulu. Hal ini terbukti bahwa, Kabupaten Bengkulu Tengah merupakan penerima dana desa terkecil selama periode tahun 2015 sampai tahun 2016, akan tetapi jumlah penduduk miskin di Kabupaten Bengkulu Tengah paling rendah dari seluruh Kabupaten di Provinsi Bengkulu.

Untuk melihat korelasi antara dana desa yang diterima pada tiap-tiap Kabupaten di Provinsi Bengkulu terhadap penurunan angka kemiskinan tahun 2015 -2018 dapat dilihat pada gambar 1. Berikut ;

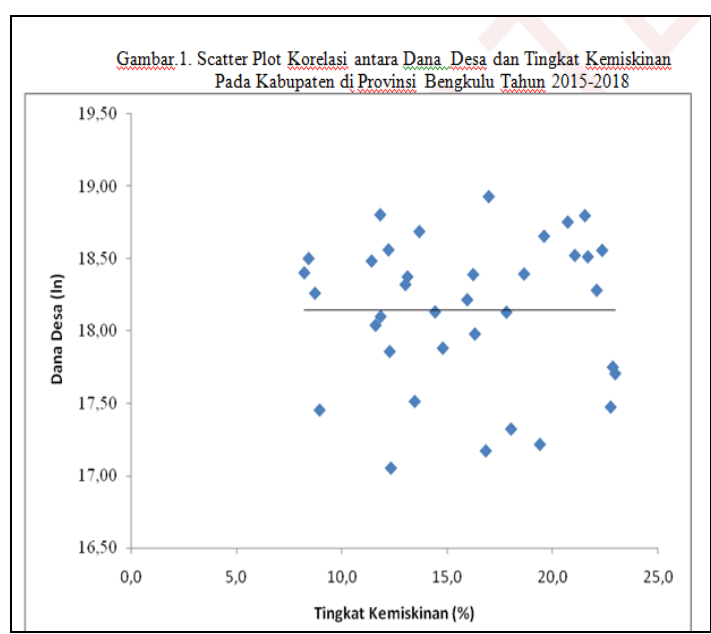

Dari gambar 1. di atas dapat dilihat bahwa penurunan angka kemiskinan tiaptiap Kabupaten di Provinsi Bengkulu tidak berkorelasi terhadap penerimaan dana desa, karena tidak terdapat kecenderungan tingkat kemiskinan terhadap dana desa yang diterima pada tiap-tiap Kabupaten di Provinsi Bengkulu. Hasil penilitian Sosilowati dkk (2017) juga menunjukkan dana desa tidak efektif dan tidak berhasil dalam mengurangi angka kemiskinan di tiap-tiap Kabupaten di Jawa Timur. Hal tersebut dikarena dana desa sebagian besar digunakan untuk sarana dan prasarana fisik pedesaan dengan kualitas rendah. Sementara jumlah masyarakat yang terlibat dalam pemberdayaan relatif kecil. Sumber daya manusia kurang memiliki kemampuan teknis dalam perencanaan dan pengelolaan dana desa.

Dalam pelaksanaan pembangunan desa keterlibatan masyarakat dalam perencanaan memiliki posisi yang sangat penting, karena pada dasarnya masyarakat yang paling mengetahui masalah dan kebutuhannya sendiri. Sistem perencanaan partisipasi memberikan kesempatan kepada individu, keluarga dan masyarakat untuk berkontribusi yang positif sesuai dengan kebutuhan dan kemampuan. Beberapa tahapan perencanaan pembangunan desa dalam pemanfaatan dana desa untuk penurunan angka kemiskinan seperti persiapan musyawarah pra-musrenbangdes, tahapan penetapan kegiatan prioritas yang akan disampaikan pada tingkat kecamatan. Pada tahapan ini seharusnya difungsikan sumber daya yang memiliki pengetahuan luas tentang masalah dan kebutuhan 
MIMBAR

JURNAL PENELITIAN SOSIAL DAN POLITIK

Juni 2019 ISSN : 2252-5270 \& E-ISSN : 2620-6056

masyarakat desa serta pemerintahan desa. Di samping itu kapabilitas individu, dan pemerintah desa dalam perencanaan pembangunan dan pengelolaan dana desa dapat membantu terwujudnya pembangunan yang bernilai ekonomi dan sesuai dengan kebutuhan masyarakat desa, sehingga dapat menurunkan angka kemiskinan. Kondisi ini akan tercapai apabila keberfungsian sosial dalam masyarakat berjalan dengan baik, sehingga individu atau pemerintah desa sebagai perencana pembangunan desa dan pengelola dana desa mengetahui kebutuhan individu, keluarga dan masyarakat desa. Malalui pendekatan keberfungsian sosial individu sebagai subjek dari segenap proses dan aktivitas kehidupannya sehingga individu memiliki strategi untuk menjangkau, memanfaatkan dan memobilisasi aset dan sumber daya yang ada disekitarnya dalam menekan angka kemiskinan.

Pembangunan sarana dan prasarana menjadi salah satu kunci dalam memacu perkembangan di desa untuk mengatasi kesenjangan dan kemiskinan. Meskipun demikian pembangunan sarana dan prasarana tersebut tidak serta-merta dapat mengatasi kesenjangan dan menurunkan angka kemiskinan di pedesaan apabila tidak disertai pula dengan usaha pembangunan manusia (human capital) dan pembangunan modal sosialnya. Kebijakan pembangunan yang lebih memprioritaskan pembangunan fisik yang kurang berimbangan dengan pembangunan non-fisik menjadi salah satu faktor penyebab kesenjangan dan penurunan angka kemiskinan diperdesaan membutuhkan waktu yang panjang.

Pembangunan sumber daya manusia berkaitan dengan kelompok miskin terkait dengan seperangkat pengetahuan dan keterampilan individu digunakan untuk mengatasi masalah kemiskinan, bagaimana keluarga miskin merespon dan mengatasi permasalahan sosial ekonomi yang terkait dengan kemiskinannya, serta bagaimana struktur rumah tangga keluarga, kerabat dan jaringan sosial mempengaruhi kehidupan orang miskin. Pendekatan ini berfokus pada apa yang dimiliki orang miskin dan bukan apa yang tidak dimiliki oleh orang miskin. Hal ini perlunya pendekatan keberfungsian sosial, menurut Edi Suharto (2009), (1) Kemiskinan dilihat secara dinamis menyangkut usaha dan kemampuan orang miskin dalam merespon kemiskinannya, hal yang pokok adalah efektifitas jaringan dalam menjalankan fungsi sosialnya, termasuk lembaga kemsyarakatan dan programprogram anti kemiskinan. Hal ini sesuai dengan Wentink, Vaandrager, Dan, Hassink, Salverda, (2017), Putra (2017), modal sosial berperan dalam membentuk jaringan. (2) menggunakan indikator komposit untuk mengukur kemiskinan, dengan unit analisis keluarga atau rumah tangga dan jaringan sosial disekitarnya. (3) lebih menekankan konsep kemampuan sosial dari pada hanya konsep pendapatan dalam memotret kondisi sekaligus kemiskinan, (4) kemampuan sosial keluarga miskin difokuskan pada beberapa indikator kunci yang mencakup kemampuan keluarga miskin dalam memperoleh mata pencaharian (livelihood capabilities), memenuhi kebutuhan dasar (basic needs fulfillment), mengelola aset (aset management), menjangkau sumber-sumber (access to resources), berpartisipasi dalam kegiatan kemasyarakatan (access to social capital), serta kemampuan dalam menghadapi goncangan (cope with shocks and stresses). Sedangkan indikator kunci untuk mengukur strategi jaringan sosial mencakup kemampuan lembaga-lembaga sosial memperoleh sumber daya alam dan sumber daya manusia, menjalankan peran dan fungsinya, mengelola aset, menjangkau sumber, partisipasi dalam program anti kemiskinan, dan peran dalam menghadapi goncangan dan tekanan sosial.

Paradigma keberfungisan sosial merupakan gabungan dari kemampuan institusi dan individu, hal ini akan membuat kajian lebih lengkap mengenai masalah kemiskinan. Pada paradigma ini kelompok miskin tidak dianggap pasif namun memiliki kemampuan dan potensi dalam mengatasi kemiskinan. Oleh kerana itu, mesyarakat pedesaan harus dapat menjangkau, memanfaatkan, dan memobilisasi aset dan sumber daya yang tersedia di desa termasuk dana desa yang telah diberikan oleh pemerintah pusat melalui pemerintah kabupaten

\section{Kesimpulan dan Saran}

Dari hasil analisis dan pembahasan dapat disimpulkan bahwa; (1) penurunan angka kemiskinan tidak berpengaruh terhadap pemberian dana desa pada tiap-tiap Kabupaten di Provinsi Bengkulu, 
(2) dalam pemanfaatan dana desa belum dilaksanakan pembangunan partisipatif dengan mengikuti tahapan perencanaan seperti; persiapan musyawarah pramusrenbangdes, tahapan penetapan kegiatan prioritas yang akan disampaikan pada tingkat kecamatan, dll. (3) kemampuan sumber daya manusia rendah dalam bidang perencanaan terutama dalam memahami masalah dan potensi desa yang bisa dikembangkan untuk perekonomian masyarakat desa, (4) tenaga teknis dalam pengelolaan dana desa sangat terbatas, (5) dana desa sebagian besar dialokasikan untuk pembangunan sarana dan prasarana dibandingkan dengan pembangunan manusia (human capital) dan pembangunan modal sosialnya. Dalam penurunan angka kemiskinan melalui program pemberian dana desa kiranya dilakukan pendekatan keberfungsian sosial antara lain; (1) kemiskinan dilihat secara dinamis menyangkut usaha dan kemampuan orang miskin dalam merespon kemiskinannya, hal yang pokok adalah efektifitas jaringan dalam menjalankan fungsi sosialnya, termasuk lembaga kemasyarakatan dan programprogram anti kemiskinan. (2) Dalam pemanfaatan dana desa perlu pembangunan partisipatif dengan mengikuti tahapan perencanaan seperti; persiapan musyawarah pra-musrenbangdes, tahapan penetapan kegiatan prioritas yang akan disampaikan pada tingkat kecamatan. (3) perlu peningkatan kualitas sumber daya manusia sebagai pengelola dana desa melalui pelatihan dan studi banding.

\section{DAFTAR PUSTAKA}

Anwar, A. 2016. Kebijaksanaan Desentraliasi Fiskal Suatu Kerangka Pemikiran Sebagai Salah Satu Aspek Penting Dalam Pelaksanaan Otonomi Daerah. Makalah disampaikan pada Simposium Nasional " Forum Mahasiswa Pascasarjana Indonesia” di Institut Pertanian Bogor 15-17 Pebruari 2001.

Lalira, D., Nakoko. A.T., Rorong.I.P.F., 2018, PENGARUH DANA DESA DAN ALOKASI DANA DESA TERHADAP TINGKAT KEMISKINAN DI KECAMATAN GEMEH KABUPATEN
KEPULAUAN TALAUD, Jurusan Ekonomi Pembangunan, Fakultas Ekonomi Dan Bisnis, Universitas Sam Ratulangi, Manado 95115, Indonesia, 62-72.

Suharto, E. (2009). Kemiskinan dan perlindungan sosial di Indonesia: menggagas model jaminan sosial universal bidang kesehatan: dilengkapi dengan: UU No. 40/2004 tentang sistem jaminan sosial nasional, UU No. 11/2009 tentang kesejahteraan sosial. Alfabeta.

Sulistiowati. N.I., Hadi. S., 2017, Pengaruh Alokasi Dana Desa, Dana Desa, Belanja Modal, Dan Produk Domestik Regional Bruto Terhadap Kemiskinan Kabupaten/Kota Di Jawa Timur . Jurnal Ilmu Ekonomi Vol 1 Jilid 2/2017 Hal. 189 - 202

Wentink, Vaandrager, Dam, Hassink, Salverda, 2017, Exploring the role of Social Capital in Urban, Citizens' initiatives in the Netherlands, Gac Sain,2017; ...................... http://dx.doi.org/10.1016/j.gaceta.201 7.05.011

Clancy, J. S. (2008). Are biofuels pro-poor? Assessing the evidence. The European Journal of Development Research, 20(3), 416-431.

Yusuf, M. B. O., Shirazi, N. S., \& MatGhani, G. (2013). The impact of Pakistan Poverty Alleviation Fund on Poverty in Pakistan: an empirical analysis. Middle-East Journal of Scientific Research, 13(10), 13351344.

\section{Buku}

Afriyanti. A.F 2016, Faktor-Faktor Yang Mengaruhi Tingkat Kemiskinan Di Provinsi Bengkulu Dan Alternatif Kebijakan Untuk Menguranginya, Departemen Ilmu Ekonomi Fakultas Ekonomi Dan Manajemen Institut Pertanian Bogor

Baker, Dubois dan Miley.1992 dalam Suharto, Edi. (2005). Membangun Masyarakat Memberdayakan Rakyat, 


\section{MIMBAR}

JURNAL PENELITIAN SOSIAL DAN POLITIK

Bandung: PT Refina Aditama.

Armida Alisjahbana, et all., 2018

Menyongsong SDGs Kesiapan

Daerah-daerah di Indonesia / Penulis,

Armida Alisjahbana, et all ; , --Cet. 2

- Bandung; Unpad Press; 2018 xviii,

324 h.; 16 x 24 cm ISBN 978-602-

439-232-1

\section{Website}

Arif.Z.N (2013, Mei 22), Kemiskinan di Indonesia atau Poverty in Indonesia, Social Media Today RSS https://bangazul.com

Departemen Keuangan, http://www.djpk.depkeu.go.id/wpcontent/uploads/2017/11/RincianAlokasi-TKDD-TA-2018-1.pdf 